\title{
Chapter 1 Animals in Our Midst: An Introduction
}

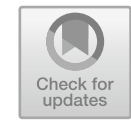

\author{
Jozef Keulartz and Bernice Bovenkerk
}

\begin{abstract}
In this introduction we describe how the world has changed for animals in the Anthropocene-the current age, in which human activities have influenced the planet on a scale never seen before. In this era, we find many different types of animals in our midst: some-in particular livestock-are both victims of and unwittingly complicit in causing the Anthropocene. Others are forced to respond to new environmental conditions. Think of animals that due to climate change can no longer survive in their native habitats or wild animals that in response to habitat loss and fragmentation are forced to live in urban areas. Some animals are being domesticated or in contrast de-domesticated, and yet others are going extinct or in contrast are being resurrected. These changing conditions have led to new tensions between humans and other animals. How can we shape our relationships with all these different animals in a rapidly changing world in such a way that both animal welfare and species diversity are not further affected? We describe how animal ethics is changing in these trying times and illustrate the impacts of Anthropocene conditions on animals by zooming in on one country where many problems, such as biodiversity loss and landscape degradation, converge, the Netherlands. We conclude by giving an overview of the different chapters in this volume, which are organised into five parts: animal agents, domesticated animals, urban animals, wild animals and animal artefacts.
\end{abstract}

\footnotetext{
Other contributions in this volume in which the Netherlands will function as a textbook example are the chapters of Hidde Boersma, Susan Ophorst and Bernice Bovenkerk, Eva Meijer and Martin Drenthen.
}

The original version of this chapter was revised: The author's name is corrected from "O'Neill, J.S. and M.H. Hastings" to "David A. Leavens" in reference cross citation and list. The correction to this chapter is available at https://doi.org/10.1007/978-3-030-63523-7_32

J. Keulartz $(\bowtie) \cdot$ B. Bovenkerk

Wageningen University and Research, Wageningen, The Netherlands

e-mail: Jozef.keulartz@wur.nl

B. Bovenkerk

e-mail: bernice.bovenkerk@wur.nl 


\subsection{Introduction}

As we are preparing this book for the publication, the world is in the grips of Covid19 , the corona virus. Scientists have traced the virus back to bats and some argue that the bats become particularly infectious when they are stressed. This stress is caused amongst other things by waking them up prematurely from their hibernation or by keeping them in captivity. ${ }^{1}$ This virus does not only have implications for humans, but also for other animals. Some have also been infected, most famously a tiger in the Bronx zoo in New York. ${ }^{2}$ Others are being used as animal models in medical experiments to find a vaccine for Covid-19. In a number of European countries, infections of mink have been met by a massive culling of all animals on mink farms in order to prevent them becoming a reservoir for COVID-19. This was done after a comparison of viral DNA that suggested that mink had infected a small number of employees (Oreshkova et al. 2020). In the Netherlands, the corona crisis has led to a debate, spurred on by the Party for the Animals, about the intensive way in which production animals are kept, with virologists stating that the Netherlands is 'full of potential hosts that can transmit a virus'. ${ }^{3}$ Globalization has certainly been a driver of the massive outbreak of this disease, and as we will argue in the introduction has had major implications for animals and for the human-animal relationship.

In the (Australian) summer of 2019/2020, large parts of Australia are on fire. So far, the devastating bushfires killed 26 people and over a billion animals. ${ }^{4}$ In particular one of Australia's main symbolic animal species, the koala, is hit hard by the fires, as its strategy is to move further up the tree in case of danger. With the fires still blazing, the Australian government is denying its own contribution to climate change and downplaying the link between climate change and the bush fires. ${ }^{5}$ Australia ranked last in the Climate Change Performance Index out of the 57 countries that are responsible for the lion's share of greenhouse gas emissions. ${ }^{6}$

In 2015, a dentist from Minnesota killed famous lion Cecil just outside of Hwange National Park in Zimbabwe. The hunt was legal, but nevertheless caused a public outcry against trophy hunting. ${ }^{7}$ This case raises difficult ethical questions, such as 'should we allow trophy hunting and even support game farms in order to raise revenue for wildlife conservation?' It also sheds interesting light on the changing

\footnotetext{
${ }^{1}$ https://www.nrc.nl/nieuws/2020/02/07/het-spoor-van-corona-leidt-naar-een-gestreste-vleermuisa3989708.

${ }^{2}$ https://www.theguardian.com/world/2020/apr/06/bronx-zoo-tiger-tests-positive-for-coronavirus.

${ }^{3}$ https://www.ad.nl/binnenland/viroloog-nederland-is-vol-met-gastheren-die-een-virus-over-kun nen-dragen-br afbc59f5/.

${ }^{4}$ https://aeon.co/essays/we-cant-stand-by-as-animals-suffer-and-die-in-their-billions.

${ }^{5} \mathrm{https} / / /$ www.vox.com/world/2020/1/8/21051756/australia-fires-climate-change-coal-politics.

${ }^{6} \mathrm{https} / / /$ newclimate.org/wp-content/uploads/2019/12/CCPI-2020-Results_Web_Version.pdf.

${ }^{7} \mathrm{https} / / /$ wildlife.org/survey-shows-u-s-citizens-increasingly-humanize-animals/?fbclid=IwAR30

Dxvy7q-B5Q_cxGrh9j-1eINgQWML4hLO9DjYK17e3YwYui6H40qP69E.
} 
attitude of humans towards other animals. A recent study suggests that people increasingly attribute human-like characteristics to wild animals, and that this anthropomorphism results in changing strategies for wildlife management. The researchers of this study notice 'a shift in values from domination, in which wildlife are for human uses, to mutualism in which wildlife are seen as part of one's social community' (Manfredo et al. 2019, 1).

In Cincinnati, two police officers sitting in a car, were approached by a goose, who started tapping on the police car's door. The goose did not respond to the food offered her, but kept on tapping, walking off, and tapping on the door again, as if asking for help. When the police officers followed her, they found her baby goose tangled up in string, and rescued the baby goose, under the watchful eye of his mother. ${ }^{8}$ This case raises interesting questions about animals' cognitive capacities and capacity for self-willed action, or agency. The goose clearly went up to the human beings planning to ask for help, expecting them to be able to afford help. Does this mean the goose is capable of intentional action? And does intentional action presuppose second-order thought? Could she even be said to possess Theory of Mind?

These and many other recent cases exemplify the changing and ambivalent relationships we have with the diverse animals that live in our midst in the Anthropocene. The term Anthropocene, which was introduced in 2000 by chemist and Nobel Prize laureate Paul Crutzen and biologist Eugene Stroemer, refers to the current age, in which human activities are so omnipresent that humanity itself has developed into a global geophysical force, at least as influential as natural forces. Even though the term would suggest otherwise, nonhuman animals in fact play an important role in the Anthropocene, not only as victims of our treatment, but also as actors in their own right. Some - in particular farm animals - unwittingly are driving forces of the Anthropocene, others are forced to respond to new environmental conditions. Think of animals who due to climate change can no longer survive in their native habitats or wild animals that in response to habitat loss and fragmentation are forced to live in urban areas. Other types of animals in our midst are (extreme breeds of) companion and sports animals, previously domesticated animals that are becoming de-domesticated, exotic and invasive species, animal species faced with extinction, and vice versa, extinct animals faced with resurrection. We witness changing relationships between these different groups of non-human animals and between human and non-human animals. ${ }^{9}$ Our integration with many of these animals has become stronger, leading to problems such as zoonotic diseases, invasions of exotic species, and human-wildlife conflicts. At the same time, our knowledge about animals and their (mental) capacities is increasing and this raises new questions about our treatment of them and about the possibilities to create shared life worlds with animals.

\footnotetext{
${ }^{8}$ https://www.homesluxury.net/goose-kept-pecking-cop-until-he-decided-to-follow-her-she-leadhim-to-her-trapped-baby/?fbclid=IwAR0ofz3B7OINuAezBAhzQKIe3sRXx3Zjran513N08rPI57 Pvydxx4g31f-0.

${ }^{9}$ For simplicity's sake we will mostly refer to non-human animals as animals and human animals as humans in this chapter.
} 


\subsection{Animal Ethics in the Anthropocene}

In the Anthropocene we face a tension in our dealings with nonhuman animals. On the one hand current research shows that animals are capable of 'self-willed action' - in other words that they possess agency (Irvine 2004). Characteristics that used to be seen as human-specific have been discovered in certain other animal species, including language use, morality, a sense of justice, altruism, complicated hierarchies, and cognition (Meijer 2019; Bekoff and Pierce 2009; Brosnan and de Waal 2012; Leavens 2007; Wasserman and Zentall 2012). This calls into question the sharp division between human and animal minds on which human exceptionalism rests - the view that humans are essentially (rather than just in degree) different from and superior to other animals (De Waal 2016; Lurz 2009; Gruen 2011). On the other hand, despite this heightened awareness of animals and their capacities, animals are increasingly limited in their agency. So even though the Anthropocene has shaped the knowledge and technology for us to realize that animals have more agency than has been assumed, ironically it is also an epoch where animal agency is increasingly curtailed. In the Anthropocene, most (vertebrate) animals live in captivity as livestock or companion animals, where humans control their movements and genetic makeup. Domesticated animals such as cows, pigs, and chickens often live in 'simple, predictable and monotonous environments', where they are hardly challenged and their agency is not stimulated (Špinka and Wemelsfelder 2011, 27). In the wild, through habitat loss and fragmentation, urban sprawl, and climate change, animal agency is also curtailed, as animals have less room to maneuver in environments suitable to their species. Due to the detrimental impact of livestock production on the environment, humans are forced to seek alternative means of producing proteins, such as cultured meat. In the Anthropocene, technology increasingly mediates our interactions with animals - from milking robots to gene editing and cloning — and this also has implications for the human-animal relationship and for animals' capability to exert their agency.

Whereas human-nature relationships figure prominently in discussions about the Anthropocene (Rolston 2012), human-animal relationships remain underdeveloped (except for Bovenkerk and Keulartz 2016; Tønnessen et al. 2016). Animal ethicists have criticized human exceptionalism (Gruen 2011), but have not yet formulated a coherent response to the specific and urgent challenges of this new epoch. The animal ethics field arose as a response to ill treatment of farm and laboratory animals, explaining its focus on individual domesticated animals, overlooking dilemmas occurring on the level of species (Bovenkerk 2016). Traditional animal ethicists (Singer 1975; Regan 1983) perceived animals as passive victims of our treatment, rather than active agents with whom we need to negotiate our common lifeworld. These theories have insufficiently thought through what it means for human-animal relationships when we take animal agency more seriously. Moreover, they could not have anticipated the variety of human-animal relationships and corresponding challenges we would be facing in this new epoch. 
In this edited volume, we have brought together authors from a range of disciplines_philosophy and ethics, ecology, communication science, linguistics, cultural geography, animal welfare science, history and law-to shed light on the changing human-animal relationships in the Anthropocene. The reader will encounter starving polar bears, greeting cows, stray cats, pedigree dogs, backyard rats, laughing chimps and roaming wolves. The question throughout is how we can give shape to new relationships with these animals. Can we find consolation in philosophy when confronted with discomforting wildlife? How do we know what is the right dog to take into our homes? Should we feed polar bears who are victim to changing climatic conditions? How can we conserve the biodiversity of animal species? Should we resurrect extinct species? These and many other questions need to be raised in our efforts to create new meaningful relationships with the animals in our midst.

This volume is divided into five parts: animal agents, domesticated animals, urban animals, wild animals, and animal artefacts. Each part is followed by a commentary. With this division we base ourselves in part on the categories of animals proposed by influential animal philosophers Sue Donaldson and Will Kymlicka. In Zoopolis (2011) they plead for a political turn in animal ethics and suggest that we grant different types of political rights to three groups of animals: domesticated, liminal, and wild animals. All animals have universal rights, such as the right not to be killed or unnecessarily harmed, but different groups of animals have differentiated additional rights. Domesticated animals are full members of our political communities and should be treated as such. We have more specific duties towards them than towards for example wild animals, because they are already part of our community; we have made decisions about the way they live and even about whether or not they live and about what their genetic composition is. They work alongside humans and fulfil important functions in our societies. According to Donaldson and Kymlicka, justice requires that we grant them citizenship rights. In their view, animals that have not been domesticated, but that live among humans, such as urban wildlife, should be termed 'liminal animals'. Think of the squirrels in our parks and the rats in our backyards. We are witnessing an increasing 'liminalisation' of wild animals, raising the question of whether this might be a precursor to their elimination (Donaldson and Kymlicka 2016, 226). In order to prevent their elimination, we will need to develop a way of cohabitation with them that protects their basic rights but that also gives us opportunities to combat the nuisance they are sometimes causing. We owe these animals similar duties as we owe to tourists who are visiting our country; they have residency without citizenship rights and are so-called denizens. Finally, wild animals have an interest in being able to live their lives as unimpeded by human interference as possible. Justice between human communities and wild animal communities could be compared to justice between countries. Wild animals should be granted sovereignty rights; the right to autonomy over their own territories. Many of the chapters in this book relate to Donaldson and Kymlicka's views in one way or another. For example, in his search for meaningful co-existence with wolves in the Netherlands, Martin Drenthen draws on their model and argues that we should see wolves as members of a sovereign community. Eva Meijer uses the concept of liminal animals to analyse the question of how we should deal with stray cats in the city. Susan Ophorst and 
Bernice Bovenkerk discuss what the notion of citizenship rights for dogs tells us about what the right choice is when obtaining a dog.

In the remainder of this introduction, we will sketch the terrain in more detail. What impacts do Anthropocene conditions such as climate change and biodiversity loss have on animals? What different groups of animals are impacted and in what ways? We will illustrate these developments by zooming in on one country where many problems, such as biodiversity loss and landscape degradation, converge, the Netherlands.

\subsection{The Netherlands as Mirror of Biodiversity Problems}

This is by no means an arbitrary choice. In the Netherlands only about $15 \%$ of the original biodiversity remains. This means that the loss of biodiversity is considerably greater than elsewhere in Europe and the world.

Almost two-thirds of the Dutch territory is used for agriculture, and two-thirds of that is used for cattle breeding. The Dutch landscape is therefore increasingly dominated by monocultures of drained rye-grass, a uniform green billiard cloth that has taken the place of flowery meadows full of birds. Landscape degradation is not only caused by intensive livestock farming, but also by the enormous number of distribution centers. The Netherlands is a distribution country par excellence. At the beginning of 2017, the country had 1760 distribution centers with a total surface area of 28 million square meters. This proliferation of distribution centers is accompanied by a substantial expansion of the transport infrastructure, making the Netherlands the most fragmented region in the whole of Europe, with disastrous consequences for the diversity of species in the Netherlands. ${ }^{10}$

Finally, there is a danger that the remaining natural landscape will be completely transformed into a recreational landscape. As a result of the increase in prosperity and mobility and the decline in leisure time, we are living in what sociologists have termed an 'experience society'. The more nature becomes an attraction, complete with mountain bike routes, pancake restaurants, souvenir shops, campsites and holiday homes, the more biodiversity will be lost.

The Netherlands, then, scores very poorly on all kinds of nature rankings. By taking a closer look at this country, one gets a sharper picture of the biodiversity problems that people and animals elsewhere also have to contend with. This is done in this introduction, in which a group portrait is sketched of the many species of animals currently found in the Netherlands, whereby we sometimes make trips to other parts of the world.

\footnotetext{
${ }^{10}$ A study from 2016 calculated that half of the European territory is situated within the critical distance of $1.5 \mathrm{~km}$ from (rail) roads. Within this area, the number of birds decreases by a quarter and the number of mammals even halves. In the Netherlands, where the distance to transport infrastructure is much smaller than the European average, we have to expect a much greater loss of biodiversity (Torres et al. 2016).
} 


\subsubsection{The Recovery of Wildlife}

We start this group portrait with a phenomenon that gives rise to some optimism. There is currently a spectacular comeback of wildlife, not only in Europe, but also in North America. The conditions for the recovery of wild populations were created by the large-scale reforestation and revegetation that took place more or less simultaneously on both continents as a result of rural depopulation. The European Common Agricultural Policy (CAP), established in 1962, has led to a far-reaching intensification of agriculture and the associated depopulation of low-productive farmland, particularly in mountain areas. Thus, while intensive agriculture leads to an impoverishment of the landscape and species diversity, it has ironically led to the return of wild animals at the same time. Another important driving force behind the return of wild populations was the emergence of the environmental movement in the 1970s, which created support for European legislation for the protection of species and habitats. ${ }^{11}$

As a result of these changes in agricultural and nature policy, the number of large grazers increased sharply. This was a prerequisite for the recovery of the populations of large predators, which were almost completely extinct in the course of the eighteenth and nineteenth centuries. A recent study, based on data from all European countries (with the exception of Russia and Belarus) for the period 2012-2016, comes to the following estimate: wolves are the most abundant with 17,000 individuals; second is the brown bear with between 15,000 and 16,000 individuals; next is the lynx with between 8000 and 9000 individuals; last is the wolverine with between 1000 and 1250 individuals (Linnell and Cretois 2018).

Also in the Netherlands many species have returned or have recovered considerably. Some species have returned spontaneously, such as the eagle owl, the crane, the white-tailed eagle and the wild cat, and also the wolf has settled here by now (see also the chapters by Jansman and by Drenthen in this Volume). Other species have been helped by reintroduction, such as the raven, the stork, the beaver, the otter, the badger, and quite recently, the bison.

\subsubsection{Exotic Species and Climate Refugees}

There is another category of wild animals that is increasingly making its presence felt in the Netherlands. These are not native species that return here after a long absence, but exotic species, that do not originally belong here, such as the muskrat, the collar parakeet and Japanese knotweed. In fact, migrating plants and animals are nothing new, but since globalization has taken off, more plants and animals have turned into 'globetrotters' than ever before. As traffic and transport, trade and tourism grow, the significance of boundaries is diminishing, and at the same time vulnerability to

\footnotetext{
${ }^{11}$ Such as the 1982 Berne Convention of the Council of Europe and the 1979 and 1992 Birds and Habitats Directives of the European Union respectively.
} 
the massive arrival of exotic species is increasing enormously everywhere. In this context, there is even talk of a 'mass migration'.

The number of registered exotic species in the Netherlands is almost 2400, an extremely conservative estimate because we do not have sufficient information for a number of species groups. With this high figure, the Netherlands is European champion of exotic species, and has the dubious honour of even being among the world's top. This is the ecological downside of international trade and the transit of goods and raw materials to the European hinterland (Leuven 2017).

Apart from globalisation, there is another important cause for the influx of exotic species, namely climate change. While cold-loving species migrate northwards, heatloving species come our way from the south. Among these newcomers are a number of pest species that can cause a lot of nuisance and also serious public health problems. One of these species that made the headlines in the spring of 2019 is the oak processionary caterpillar. This moth caterpillar, whose numbers has tripled in the Netherlands since 2018, causes complaints such as itching, rash, and irritation to the eyes or respiratory tract. The pine processionary caterpillar, which has even more burning hairs than the oak processionary caterpillar, has already moved into the Belgian Ardennes. Other species that threaten to settle here are the Asian Tiger Mosquito, which can transmit tropical diseases such as chikunguna, dengue and zika, and the Hyalomatick, a giant tick that can transmit the dangerous Crimean Congovirus.

While thermophilic species are advancing, cold-loving species are increasingly getting into trouble. This is especially true for plants that can only move very slowly to colder areas because they can only move by spreading their seeds. It also applies to cold-blooded animals, such as insects, fish, reptiles and amphibians, whose body temperature depends on the ambient temperature and who are therefore very sensitive to climate change. These animals all too often encounter obstacles that are difficult to overcome in the form of natural barriers, such as mountains and rivers, or in the form of infrastructural works, such as motorways, railways and viaducts. In order to save these animals from extinction, wildlife managers sometimes resort to what is known as assisted migration or assisted colonisation: the deliberate relocation of these 'climate refugees' to new habitats that they cannot reach on their own (see Larson and Barr 2016).

\subsubsection{The Sixth Mass Extinction}

All in all, a lot of wild animals, spontaneously or otherwise, have returned to the Netherlands or emigrated here. But let's not get too excited yet: in the Anthropocene, the age of humans, we are confronted with a worldwide extinction wave. We must therefore assess the recent increase in wild populations in the light of dramatic historical declines: most of the populations of species in the process of comeback are still far from reaching a genetically and demographically sustainable size, while many species are still declining in size. In fact, we are in the midst of a new mass 
extinction. Mass extinction occurs when the earth loses more than three-quarters of its species. This has only happened five times in the course of Earth's history, the last time 65 million years ago when the dinosaurs disappeared from the face of the earth. Experts estimate that the current rate of species extinction is 100-1000 times higher than the so-called background extinction rate.

In order to be able to assess the situation properly, we need to pay attention not only to the extinction of species but also to the decline in the number and size of populations. WWF's latest Living Planet Report (2018) shows that the size of vertebrate populations fell by no less than $60 \%$ between 1970 and $2014 .{ }^{12}$ When we realise that population extinction should be seen as a prelude to species extinction, it becomes clear that "the window for effective action is very short, probably two or three decades at most" (Ceballos et al. 2017).

When we now turn our gaze to Dutch nature, we see a rather dramatic picture. This is evident from the Living Planet Report: Nature in the Netherlands, a report published by WWF at the end of 2015, in collaboration with a large number of nature organisations. According to the report, animal populations in nature reserves have declined by an average of $30 \%$ since 1990. The most recent State of Nature in the $E U$, a report published by the European Environment Agency in 2015, shows that the Netherlands, with no less than $96 \%$ of nature areas in an unfavourable condition, is at the very bottom of the list of all $26 \mathrm{EU}$ member states.

\subsubsection{Rewilding and De-extinction}

It is a widespread misunderstanding that the extinction crisis only began during the era of the great discoveries, from the end of the fifteenth century until the eighteenth century. This crisis began as early as the transition from Pleistocene to Holocene, around the end of the last Ice Age, some 11,000 years ago. The main victims were the megafauna species, a group of mammals considerably larger than the current mammals, such as mammoths, mastodons, sabre-toothed tigers, ground sloths, cave bears, giant wolves and giant deer. ${ }^{13}$

To explain this tremendous loss of mega-fauna species, four hypotheses have been put forward, known tongue-in-cheek as 'overkill', 'overchill', 'overill' and 'overgrill'. The 'overkill' hypothesis blames the extinction of megafauna species on the spread of modern humans (Homo sapiens). The 'overchill' hypothesis puts the blame on climate change at the end of the Pleistocene, the 'overill' hypothesis on some 'hyper disease', and the 'overgrill' on a comet impact or shock wave above North America (Wolverton 2010). Because there is hardly any support for the last two hypotheses ('overill' and 'overgrill'), the research has mainly focused on the role of climate change and the role of the hominids. The outcome of this research is that the

\footnotetext{
${ }^{12}$ Invertebrate populations are also in a precarious situation; their size has decreased by $45 \%$ over the last 4 decades (Dirzo et al. 2014).

${ }^{13}$ The term megafauna refers to large mammals weighing more than $45 \mathrm{~kg}$.
} 
extinction of megafauna species is strongly related to the prehistoric geographical distribution of hominins and only weakly related to interglacial climate changes.

There is a significant difference in the magnitude of megafauna extinctions between sub-Saharan Africa, where hominins and megafauna have long coexisted, and Australia and America, where Homo sapiens were the first hominin species to arrive. While megafauna extinctions were universally low in sub-Saharan Africa, they were exceptionally high in Australia and the Americas. Eurasia, where megafauna came into contact with hominins long before the arrival of Homo sapiens, falls between these extremes. It has been suggested that these differences stem from the 'naivety' of prey animals that had not (yet) learned how to defend themselves against a new predator with advanced hunting techniques (Sandom et al. 2014).

The great loss of megafauna species is ecologically disastrous. Large carnivores, who are at the top of the food pyramid, exert a strong influence on the animal and plant populations that are at a lower level of the food pyramid and therefore play a key role in the regulation of ecosystems. They regulate the size and behaviour of prey populations, the small and medium-sized herbivores and the so-called 'mesopredators' that hunt smaller animals. Large herbivores, which are largely resistant to predation, also have an important influence on ecosystems, especially on the structure and composition of their vegetation (Terborgh et al. 2010; Svenning et al. 2016).

To compensate for the dramatic loss of megafauna, rewilders use a multitude of methods and techniques. In the case of globally extinct species one can try to make use of ecological substitutes for these species. Under the title of 'Pleistocene rewilding', American restoration biologists are considering using the megafauna still present in Africa and Asia, such as cheetahs, lions, camels and elephants, as replacements for the extinct American species.

More recently, a number of new technologies have been developed that make it possible to revitalise extinct species, a practice known as de-extinction. Two methods from synthetic biology are currently in vogue to bring back extinct species: Cloning via somatic cell core transplantation (SCNT) and genetic modification using CRISPR/Cas technology. The most spectacular de-extinction project using the latter technology aims to bring the woolly mammoth back to life. ${ }^{14}$

In addition to cloning and genetic modification, there is a third, less controversial method of de-extinction, namely back breeding: the crossing and selection of domesticated breeds with the aim of bringing back the traits of the wild extinct ancestors of these breeds. Such semi-wild breeds played an important role in Dutch nature policy. In 1983, 32 Heck cattle were introduced to the 'new nature area' Oostvaardersplassen. The cattle were named after the brothers Heinz and Lutz Heck, who in the 1920s and 1930s tried to breed back the aurochs (Bos primigenius), that went extinct in 1627 , by means of crossbreeding with primitive breeds such as the Camargue cattle, the Hungarian Steppenrund and the Scottish Highlander. One year later, 20 konik horses followed; they are the result of attempts by the Polish agronomist and biologist Tadeasz Vetulai of the University of Poznań to breed back the wild tarpan horse (Equus ferus ferus), which became extinct in 1887.

\footnotetext{
${ }^{14}$ See https://reviverestore.org/projects/woolly-mammoth/.
} 


\subsubsection{Intensive Livestock Farming ${ }^{15}$}

The extent to which wild animals have become oppressed worldwide is abundantly clear from the fact that the biomass of all people on earth is ten times greater than that of all wild land mammals combined, while the biomass of domestic animals-farm animals and companion animals - is as much as 35 times greater than that of all wild land mammals combined. Among the vertebrates, Homo sapiens and Bos Taurus have become by far the most dominant species on earth.

\section{Biomass of all the land mammals on planet Earth:}

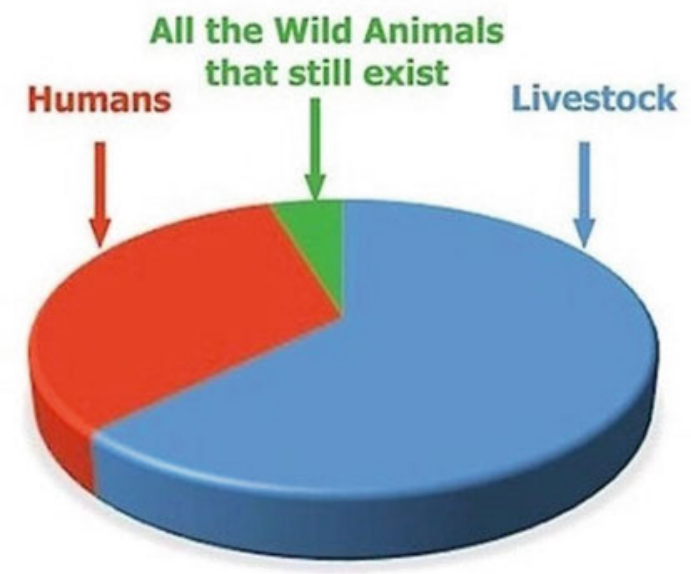

Based on Vaclav Smil (2011)

In the Netherlands those proportions are even a lot more unbalanced. With 502 inhabitants per $\mathrm{km}^{2}$ our country ranks fourth among the most densely populated countries in the world (after Bangladesh, Taiwan and South Korea) but at the same time it is also the second largest exporter of agricultural products in the world (after the US). ${ }^{16}$ In terms of livestock density, the Netherlands is even at the top of the world's rankings. The number of farm animals in 2016 was more than 126 million. The largest group is made up of 105 million chickens, followed by 12 million pigs and 4 million cattle. However, the share of livestock farming in the Gross Domestic Product (GDP) is only a mere $0.6 \% .^{17}$

The large amount of land taken up by livestock farming is causing serious biodiversity problems. If we do not include the production forests, only $13 \%$ is currently left for nature, half of which consists of large inland waters such as the Wadden

\footnotetext{
${ }^{15}$ We would like to thank Joost van Herten for his critical reading of and comments to this section.

16 This ranking does not take into account small city-states and small islands or island groups with very high population densities.

${ }^{17}$ This is despite strong productivity growth as a result of the processes of intensification and economies of scale, the contribution of agriculture to GDP fell from 15 to $1.5 \%$ in the period 1950 2015 , less than half of which is accounted for by livestock farming. http://www.clo.nl/indicatoren/ nl2125-productiewaarde-landbouw.
} 
Sea and lake IJsselmeer. The size of our livestock population causes biodiversity problems outside of the Netherlands as well. Our livestock is so large that it can only be partially fed on fodder grown here. The Netherlands is the world's second largest importer of soy after China. Although two-thirds of the soy is exported to the European hinterland, with what remains behind, the Netherlands is still the fifth largest soy user in Europe. To grow the soy that we import annually for our livestock, we need an area as large as three-quarters of the Netherlands. A lot of tropical rainforest is deforested, with disastrous consequences for the richness of local species.

The high density of livestock not only compromises the space for nature, but also leads to major environmental problems that affect the quality of nature. The Netherlands has the highest nitrogen and phosphate surpluses of all EU member states. ${ }^{18}$ Nitrogen ends up in the air in the form of ammonia, either directly from the stables or after fertilising the land. The very high ammonia emissions lead to acidification and eutrophication of nature areas and thus have a very detrimental effect on biodiversity and also on the quality of ground and surface water. ${ }^{19}$ Livestock farming is also responsible for the emission of large quantities of carbon dioxide, methane and nitrous oxide.

The high livestock density causes not only biodiversity problems but also all kinds of animal welfare problems. The lack of room to move of the tightly housed farm animals leads to aggressive behaviour of the animals, which in turn necessitates controversial interventions such as the dehorning of cows and calves, the docking of pig tails to prevent tail biting, and the cutting of chicken beaks to prevent cannibalism. In addition, the high density of livestock regularly leads to outbreaks of animal diseases such as foot and mouth disease (FMD), and swine fever. Mainly for economic reasons, animals are usually 'culled', i.e. slaughtered on a large scale in order to make the herd disease-free again. And then there are the many barn fires in which sometimes more than two hundred thousand animals are burnt alive in one year.

Finally, the high density of livestock also causes public health problems. Some animal diseases, so-called 'zoonoses', such as Q-fever and bird flu, are transmissible to humans. The excessive use of antibiotics in animal husbandry also has harmful consequences for public health. ${ }^{20}$ It can lead to bacterial resistance and thus to a decrease in the efficacy of antibiotics that are also used in human health care. Finally, livestock farming, through the emission of ammonia which is converted into particulate matter in the air, increases the risk of respiratory problems for people living near

\footnotetext{
18 Our country does not even manage to meet the conditions of the so-called 'derogation', which allows Dutch livestock farmers to use 250 instead of 170 kilos of nitrogen from animal manure per hectare of land, in derogation of the European Nitrates Directive.

${ }^{19}$ In recent years fertilisation has led to environmental standards being exceeded in 86 of the 220 drinking water wells in the Netherlands.

${ }^{20}$ Fortunately, due to stricter regulations, the use of antibiotics in animal husbandry has decreased by $63.8 \%$ since 2009 in the Netherlands. See https://cdn.i-pulse.nl/autoriteitdiergeneesmiddelen/ userfiles/sda\%20jaarrapporten\%20ab-gebruik/AB-rapport\%202018/sda-rapportage-2018-def-err. pdf. In the whole of Europe it has decreased by $32 \%$ between 2011 and 2017. See https://www. ema.europa.eu/en/veterinary-regulatory/overview/antimicrobial-resistance/european-surveillanceveterinary-antimicrobial-consumption-esvac.
} 
animal farms. The conclusion seems inescapable: what is needed first and foremost to create space for wild animals is a substantial shrinkage of the herd.

\subsubsection{The Ecological Impact of Large-Scale Hunting}

However, more space for nature is not only a matter of the number of hectares, but above all concerns the management of nature areas. This management must provide space for wild animals to fulfil their ecological role, thereby giving natural processes that are essential for the much-needed restoration of biodiversity a chance again. In current wildlife management, however, that space is severely restricted because of the central position of large-scale hunting. Take the fox, which is currently hunted in order to protect meadow birds. Bird numbers have fallen sharply since the varied, flowery grasslands, on which the meadow birds depend for food, mating and nesting, gave way to monocultures of drained English rye-grass lands, from which all life has disappeared. It seems unfair and disproportional to punish foxes for the birds' demise.

Besides the fox, many other wild animals are hunted. For decades, the Netherlands has had a 'zero tolerance' policy for large game, such as fallow deer, red deer and wild boar. The animals are only tolerated in a very limited number of nature reserves. If they leave these areas, they will be shot. But even within these areas, large numbers of deer and boars are shot. By far the most important justification for large-scale hunting is the prevention of damage to agricultural crops and of injuries as a result of traffic accidents. As damage increases with the number of animals present in an area, the density of game populations is hunted down to a level acceptable to farmers, foresters, private landowners and other interest groups. This is also referred to as 'societal carrying capacity'.

The socially determined target densities are extremely low: for red deer and wild boar, target densities of 2-3 animals per 100 ha are by no means unusual. In order to achieve these low targets, huge numbers of large ungulates have to be shot every year. Shooting percentages of 60-70\% for red deer and 80-90\% for wild boar occur regularly. As a result, the animals can hardly have any influence on their habitat and are in fact ecologically eliminated. Some animal species that were locally extinct, such as the beaver, have been reintroduced with a lot of publicity (and subsidy) as an asset to Dutch nature, but then declared outlawed when the success of this action started causing us discomfort.

\subsubsection{Companion Animals}

Besides farm animals, people also keep large numbers of pets in the Netherlands. North America is the world's leading country in pet-keeping; the country has over 300 million pets, which is four times the number of children. In the Netherlands 
no less than $60 \%$ of households have a pet. In total, about 35 million animals are involved. The list is led by fish, carrier pigeons and singing and ornamental birds, followed by cats and dogs. In addition, rabbits, other rodents and reptiles are also kept in large numbers.

Many of our pets suffer from serious health and welfare problems. This is especially true for pedigree dogs, which make up about a quarter of the two million dogs in the Netherlands. They are condemned to an inadequate and unhealthy existence by breeding for extreme external characteristics and breeding with a gene pool that is too small. Just think of the English Bulldog, who suffers from shortness of breath because of his characteristic large head with a flat snout; the German Shepherd Dog, who has a very high risk of hip dysplasia and wear and tear of the dorsal vertebrae because of his sharply sloping hip; the Shar-Pei, who suffers from all kinds of allergies and skin infections due to his exaggerated folds; the Shih Tzu, who suffers from respiratory problems due to his flat snout and also has a risk of corneal inflammation due to his protruding eyes, and the list goes on.

The discussion on the issue of rearing pedigree dogs should not only address the complaints and ailments which these animals face, but also the underlying question of whether we should be allowed to control the genetic composition of animals to such an extent that we actually create human artefacts (Bovenkerk and Nijland 2017).

But pets do not only have problems, they also cause problems themselves. This applies to dogs, who can be involved in biting incidents and the transfer of zoonoses (see also Ophorst and Bovenkerk in this volume) but also for example to cats, who pose a serious threat to biodiversity in our country. In their book Cat wars: The devastating consequences of a cuddly killer, published in 2016, Peter Marra, director of the Smithsonian Migratory Bird Center, and journalist Chris Santella defend the proposition that cats cause serious ecological damage worldwide. These cuddly animals are in fact super-predators that threaten many endemic species with extinction, a problem that is particularly acute on isolated islands. In the United States, cats are said to devour 1.3-4 billion birds and 6.3-22.3 billion mammals annually, with stray cats accounting for $70 \%$ and domestic cats for the rest. In the United States, according to Marra and Santella, "more birds and mammals die in cats' mouths than from pesticides and toxins, from collisions with wind turbines, cars and skyscrapers, and from all other anthropogenic causes combined" (Marra and Santella 2016, 69). Three to four million domestic cats live in the Netherlands and the number of stray cats is estimated at 135,000-1.2 million (for a discussion on how to co-exist with stray cats, see Eva Meijer in this volume). According to a rather conservative estimate, we must assume that domestic and stray cats kill 100 million and 50 million prey annually respectively, mainly birds, but also mammals, reptiles and amphibians, including endangered species (Knol 2015). ${ }^{21}$

\footnotetext{
${ }^{21}$ Given the ecological impact of cats, Marra and Santella argue for house cats to be kept indoors and obliged to be chipped, registered and sterilised, and for stray cats to be offered for adoption. This appears to be a declaration of war to cat lovers for whom these animals are sacred. Marra now receives death threats and is portrayed as a Josef Mengele propagating the mass extermination of cats. The Huffington Post even suggested that he would call for cats to be clubbed to death and shot. In the Netherlands, recently two legal scholars have called for a duty to keep cats on a leash when
} 


\subsubsection{The 'Liminalisation' of Wildlife}

One of the most important consequences of the scaling up and intensification of agriculture is the migration of many wild animals to villages and towns. One example is the oystercatcher, which had already gone through a transition from coastal bird to meadow bird and is now seeking refuge in the city, on the roof of hardware stores and schools. Another example of the migration to the built and inhabited world is the stone marten. The disappearance of small-scale agriculture is to blame for its relocation. Particularly because modern stables are no longer suitable as a place to rest and sleep, the stone marten has moved to villages and cities where, in addition to sufficient food, it can also find a warm shelter.

There are many other examples of wildlife advancing to urban areas. With many thousands of boars, Berlin has now been proclaimed the 'capital of the wild boar'. When it comes to foxes, London is undoubtedly the first city to qualify for such a title. In the Netherlands there is similarly a steady increase in city foxes and boar, and also city deer, just think of the fallow deer that roam in a number of coastal cities, such as Zandvoort.

As a result of the forced migration to urban areas due to a growing lack of space, more and more wild animals acquire the status of liminal animals (Donaldson and Kymlicka 2011). Although liminal animals are our co-inhabitants, according to Donaldson and Kymlicka we should not treat them as fellow citizens, as we should do with domesticated animals. Since deportation (to the wilderness) or domestication (to farm or pet) are not real options for the majority of liminal animals, we must accept their presence; we must give liminal animals a certain right of residence and not treat them as pariahs and make their lives unnecessarily difficult or completely impossible. On the other hand, they are not entitled to full citizenship rights. We must exercise extreme restraint in our contacts with liminal animals; we must not feed them or make friendly relations with them. This only leads to conflicts of which the animals themselves are the victims. We must develop forms of co-existence in which the right of residence of liminal animals is protected but in which we can also combat the nuisance these animals may cause, for example by reducing populations through contraceptive methods, or by restricting access to buildings by means of fences and grids (see also Drenthen in this Volume).

\subsubsection{The Struggle for Nature Between People}

As we hope to have made clear, the growing presence of animals in our midst raises many questions to which we often do not have the answer. How to deal with the

outside (Trouwborst and Somsen 2019). This was also met with fierce criticism. As Eva Meijer convincingly argues in Chapter 16, stray cats have agency which should be taken into account. However, there is a clear tension with the agency of their prey animals and this tension at least should be the topic of public debate in our view. 
environmental and welfare problems in the increasingly intensive livestock farming? What about the many millions of companion animals that inhabit our country? How to live together with wild animals such as geese and wild boar? Should we help the climate refugees among the animals through assisted migration? How do we treat foxes, peregrine falcons and other wild animals that are currently moving into our cities? How to deal with the many exotic species that come to us in large numbers through world trade and mass tourism? And what about the animals that are in danger of disappearing from our midst due to extinction? In short: how can we shape our relationships with all these different animals in a rapidly changing world in such a way that both animal welfare and species diversity are not further affected?

The answers to these questions vary strongly. The fight for the animals is mainly a battle between people, also between people who personally care about the animals and/or are professionally involved in the policy and management of animals. All too often animal protectionists are at odds with nature conservationists. But even between conservationists it is not always easy, as there are often fundamental differences.

Conflicts between animal protectionists and conservationists are mainly about the contrast between individualism and holism. Animal protectionists generally give priority to the welfare and rights of individual animals and tend to downplay the importance of species conservation and the prevention of biodiversity loss. Nature conservationists oppose this individualistic approach; they embrace a more holistic view in which individual organisms are seen as part of a larger whole, such as communities, species or ecosystems, and tend to subordinate animal welfare and rights to the importance of species conservation.

Conflicts between conservationists are mainly about the contrast between the separation and the interweaving of nature and culture. This contrast is central to the discord between the primitive and the pastoral representation of the ideal-Arcadian-landscape. While primitive Arcadia is inhabited by people who behave like wildebeests, all dangerous creatures (such as the lion and the snake) have been banished from pastoral Arcadia and the ideal animals (such as the cow and the bee) behave like dutiful and industrious citizens. Because both imaginations of the ideal landscape are at odds, there is a constant struggle between them, which, according to the British historian Schama (1995), even extends into debates within nature conservation and the environmental movement, 'between the brighter and paler shades of green'.

This thesis also holds true for Dutch nature policy, which for decades has been torn between the pastoral and the primitive representation of the ideal landscape. The Dutch model of the pastoral imagination par excellence is formed by the preindustrial landscape of yesteryear, which can only be maintained by old agricultural techniques. The primitive imagination is not about maintaining patterns that have arisen in the course of the history of human habitation and exploitation, but about striving to keep natural processes as undisturbed as possible. To achieve this, human intervention must be kept to a minimum: 'hands off' is the motto. While the pastorals advocate an integration of culture and nature, the primitives are in favor of a strict separation between the two. In other words, the pastorals have a human-inclusive 
vision of nature and cherish an interventionist management of nature, while the primitives have a human-exclusive vision and are explicitly non-interventionist.

The contrast between separation and integration also plays a role in the debate between the established, traditional conservationists and the so-called ecomodernists. The ecomodernists distance themselves from the doom and gloom of the old nature movement, which the Anthropocene sees exclusively as a potential ecological disaster. Instead, they welcome this era as a new step in the progress of mankind. In their view, man is not a pest species, as some traditional conservationists seem to think, but a 'God species'. The techno-phobia of the traditional nature movement is giving way to a pronounced techno-triumphalism among the ecomodernists. And ecomodernists see industry not so much as a culprit but rather as an ally (see Keulartz and Bovenkerk 2016).

Whereas the traditional nature movement generally advocates nature-inclusive forms of agriculture, such as organic or ecological agriculture, ecomodernists want to 'decouple' man and nature and save space for nature by further intensifying agriculture. Here the contrast between separation and integration returns, in the form of the duo land sparing and land sharing.

\subsection{Overview of the Volume}

Besides the land sparing versus land sharing tension, a number of other tensions are thematised-implicitly or explicitly-in this book. Firstly, we find the aforementioned tension between our awareness of animal agency and the efforts of humans to curtail this agency. How can we do research into animals' agency if these animals are raised in conditions that impoverish their capacities for expressing their agency? How can we take animal agency seriously, while at the same time dealing with potential harmful expressions of this agency (such as in the case of stray cats)? Should we emphasize the differences or rather the similarities between humans and other animals?

Secondly, there is the aforementioned tension between those focussing on individual animals who tend to view all animals as domestic animals that we need to take care of and those focussing on wild animals, who tend to have a laissez-faire attitude. Do we allow wild zoo animals to exhibit behaviours that are not considered wild, but that do appear conducive to their welfare? How to deal with wild animals that due to climate change can only survive if they are fed by humans, such as polar bears, if this means they lose part of their wild status?

Thirdly, we find a tension between different responses to the Anthropocene, including the role of technology. Traditional conservationists call for a modest attitude towards other animals and nature. They emphasize the negative consequences of human actions and look for ways of righting the wrongs we have committed in the past. Ecomodernists on the other hand, welcome the Anthropocene as an opportunity to increase human welfare worldwide through careful governing and management of nature: because of modern technology, we no longer need to worry about planetary 
boundaries, but can simply redesign Earth for our own benefit. With their exclusive focus on humans, ecomodernists may ignore animal agency. Some plead for intensification of agriculture, including livestock farming. However, because livestock farming is driven by efficiency, it increasingly upscales to ever larger facilities and becomes more technology dependent. Such circumstances increasingly limit animal agency. Other ecomodernists, however, such as Hidde Boersma in this volume, argue for a decrease in meat consumption and the development of cultured meat. Technology does not necessarily curtail animal agency, but could potentially be used to augment it as well. Is a middle road possible between technology-shy conservationists and technology optimistic ecomodernists, like Cor van der Weele argues?

This volume is divided into five parts, on the basis of different types of animal: animal agents, domesticated animals, urban animals, wild animals, and finally, animal artefacts. After this introduction we have included a second introduction, written by Hugh Jansman from a wildlife-ecological perspective. The purpose of this chapter is to give the reader some theoretical and empirical background to the conservation issues that form the backdrop of many of the chapters in this volume. Jansman argues, again taking the Netherlands as an example, that our conservation efforts should focus more on the level of viable ecosystems. He proposes a strategic plan to do so, which is called Cores, Corridors and Carnivores. This involves setting aside more space for nature and natural processes, including top-down forcing by apex consumers (in particular large predators) and finding a way of coexistence with our fellow creatures. He discussed the cases of red deer and wolves in the Netherlands by way of illustration and concludes with a vision of what the Netherlands could look like a hundred years from now.

\subsubsection{Part 1: Animal Agents}

The first part of this volume deals with the capacities of animals and what they mean for our treatment of them. Many discussions about animal welfare betray a limited understanding of animals. For example, only the way animals' lives are ended are regarded as problematic. This seems based on a narrow understanding of animal welfare as one of being free from pain, hunger and thirst. Meijer and Bovenkerk present a broader vision of animals as agents. In their chapter, they defend a relational approach to animal ethics, viewing other animals as subjects capable of co-shaping relations. Charlotte Blattner examines how animal agency is dealt with in the law and encounters deep-seated anthropocentric biases. The authors of both chapters call for new forms of research that take animal agency seriously. The following three chapters each deal with foundational issues in animal ethics that have an influence on how we regard animal agency. Nathan Kowalsky argues that the common strategy in animal ethics to base moral consideration on the similarities humans share with nonhuman animals is really a disguised form of anthropocentrism. He proposes an ethic of animal difference that does justice to animals' otherness without being imperialist. Jozef Keulartz analyses a problem that has been at the heart of animal ethics ever 
since animal rights were proposed: the predation problem. If we take animal agency seriously, we should grant predators the opportunity to manage their own affairs and refrain from protecting prey animals against them. Perhaps counter-intuitively, he argues firstly, that if we want to take prey animals' agency seriously we should also allow predation and secondly, that this is only possible in the Anthropocene if we manage wild populations. The latter raises a tension for animal agency: conservation may necessitate keeping wild animals in zoos, but this could interfere with their wild animal agency. John Basl and Ronald Sandler revisit the central discussion in animal ethics about what entities should be attributed moral status. They defend the view that species partiality in consideration and treatment of animals is possible without the need to adopt a species-membership or human-privilege view on moral status. Finally, Michiel Korthals places the discussion about animal agency in a broader context. Focussing on the complexity of relationships between different living organisms he highlights the ways in which organisms select and value specific items in their network of living and non-living entities. In his comment to this part, Joost Leuven calls attention to the societal and moral urgency of more research into animal agency, in a human-dominated Anthropocene.

\subsubsection{Part 2: Domesticated Animals}

Part two focuses on domesticated animals. Intensive livestock farming in particular is greatly implicated in creating the Anthropocene, and current farming systems are organised in such a way that animals' agency is hardly taken into account, influencing the relationship between humans and farmed animals. Plant-based meat substitutes and in vitro meat and milk are increasingly pursued, but technological solutions to improve intensive farming systems are also sought. How can we reshape our relationship with the animals we have domesticated, be it for companion or for their products? Hidde Boersma sets the scene of this part by zooming in on the production and consumption of animal protein and its detrimental impact on the planet. He gives the reader insight into the ecomodernist mindset and proposes a diverse strategy: on the consumption side he argues for a move from beef to chicken and pork, a reduced consumption of meat and the consumption of lab grown meat. On the production side he argues for intensification of the production process through the closing of global yield gaps between the best and the worst performers and through the development of novel integrated indoor systems like agroparks. Drawing on a combination of ethnographic fieldwork and critical theoretical inquiry, Leonie Cornips and Louis van den Hengel examine how dairy cows, whose freedom is profoundly restricted by bars and fences, nevertheless enact social and linguistic agency. The chapter thereby reflects on the role of language in changing human-animal relationships. The third chapter in this section that focuses on the conditions of animal protein production is written by renowned agricultural and food ethics professor Paul Thompson. He calls on philosophers to not simply reject intensive livestock farming, but to engage with producers and scientists in order to improve animal welfare standards. Andrea 
De Paula Vieira and Raymond Anthony focus on a neglected topic in animal ethics: how to prepare for emergencies and disasters that not only affect humans, but also non-human animals? What happens to animals when disaster strikes? The authors present six ethical stewardship caretaking aims for emergency preparedness and response and a number of recommendations for reasonable decision-making the face of emergencies. The final chapter of this section, by Susan Ophorst and Bernice Bovenkerk deals with the quintessential companion animal: the dog. They point out several problems related to dog-keeping, such as aggression, zoonosis, health-and welfare problems due to exaggerated breeding standards. As dogs were domesticated so long ago these problems might be a precursor to problems other human-animal relationships may face in the Anthropocene. In their view, many of these problems can be traced back to one moment: the decision-moment of wannabe dog keepers. In his comment, Erno Eskens focuses on the opposition between animal rights defenders on the one hand and 'non-ideal animal ethicists' on the other. The latter are of the opinion that we can improve animal welfare gradually by appealing to standards of human decency. Eskens is rather sceptical of this position, because it might in fact move us in the opposite direction of an ideal situation. Yet, he acknowledges no-one has a clear vision of what such an ideal situation actually is.

\subsubsection{Part 3: Urban Animals}

In part three urban animals are central. One of the most important consequences of upscaling and intensification of agriculture, in combination with management of wild animals, and habitat fragmentation is the colonization of urban areas by wild animals. So, although wildlife becomes extinct in many places, it magically appears in the midst of urban life-in zoos, nature parks, and popular culture. How can we defend ourselves against the nuisance these animals may cause while taking into account their interests and agency as well? Possible examples could be reducing out of control populations with birth control or limiting access to buildings with fences and screens. But how far are we allowed to go with these measures? What meaningful ways of cohabitation can we develop? Besides liminal animals, we find another category of urban animals: wild animals living in captivity, most notably in zoos. The justification of keeping animals in zoos is increasingly up for discussion and at the same time zoos are keeping up with the times by changing their raison d'être, their designs and management practices, focussing more on conservation and more closely mimicking natural habitats. Is it justified to take away animals' liberty? Are we allowed to 'sacrifice' the individual animal for the sake of its species? How can zoos take into account animals' agency better? In her chapter, Eva Meijer narrates the story the Amsterdam Stray Cat Foundation, who in their practices and views they challenge common assumptions about cat subjectivity and agency, the cats' right to a habitat and social relations, as well as the idea that there is a strict difference between cats and humans. Joachim Nieuwland and Franck Meijboom deal with liminal animals that are even less wanted in cities: rats. They consider the question 
in what way the aversion people feel towards rats affects moral deliberation about pest management and about animal political theory in general. Next, we turn to zoos. Yulia Kisora and Clemens Driessen examine narratives about two orangutans in zoos: Jinga, who has become famous on Youtube for laughing at a magic trick, and Jacky, whose video where he plays 'catch the banana' with a zoo visitor has gone viral on Youtube as well. Their interpretation of the comments underneath the videos shows that such virtual interactions between humans and zoo animals can serve to cast doubt on the division between the human and the animal. It also shows the ethical potential of these interactions to either reinforce or question common practices of dealing with wild animals. Animal welfare specialists Sabrina Brando and Elizabeth Herrelko in their chapter give the reader a look behind the scenes of zoos and ask the question what role zoos can play in connecting people with nature. They discuss a number of dilemmas that modern zoos face. For example: how to give zoo animals sufficient choice and control over their environment and activities? How to deal with animals who choose to engage in behaviour that does contribute to their welfare, but that appears to undermine their wild status? And how can we make sure that the conservation message still comes across even if zoo animals are perceived as less wild? In her comment to this section, Lauren van Patter ponders the challenges different types of animals face due to urbanisation. Asking how animals can make a living within the city is both a spatial question, involving human judgments about who belongs where, who is wanted and who is a pest, and an ethical question about what rights animals have to the city.

\subsubsection{Part 4: Wild Animals}

Part four deals with our relationship to wild animals. Habitat fragmentation, urban sprawl and species invasions resulting from globalisation have curtailed animals' freedom of movement, but at the same time our interactions with 'wild' animals have become more numerous. Many people rejoice about the return of wild animals such as the wolf and sea eagle, while having doubts about how to co-exist with these animals. Modern (bio) technologies are employed to deal with species loss and to enable coexistence with animals, raising moral questions. We can discern two opposing trends: On the one hand, nature conservation efforts, intensification of agriculture-leading to an exodus out of rural areas - and global traffic, trade and tourism-bringing in exotic species-have led to a comeback and proliferation of wild animals in Europe and North-America. On the other hand, we are witnessing the sixth mass extinction of species. How can we help wild animals to cope with challenges posed by the Anthropocene: climate change, habitat loss, and biodiversity loss? How can we adapt animals and their lifeworld in a responsible manner so that they can survive in a world dominated by humans? Should we engage in assisted migration or intervening in wild populations by supplementary feeding or giving veterinary care? The latter question is addressed by well-known animal ethicist Clare Palmer, who looks into the plight of polar bears. How should we respond to the suffering of individual polar 
bears due to the effects of climate change? Would aid to the bears result in park-like management of some bear populations and the associated loss of wildness? Ned Hettinger in his chapter defends the preference for native species against criticism of being, amongst others, incoherent and xenophobic. What are the implications of such a preference for non-native, sentient animals? Both Martin Drenthen and Mateusz Tokarski in their chapters discuss the recolonisation and repopulation of wild animals, in particular wolves, into humanized cultural landscapes. What does such recolonisation mean and how can we learn to co-exist with these animals? Drenthen, drawing on Donaldson and Kymlicka, argues that we should regard wolves as sovereign beings belonging to a sovereign community. In his view, fences should be regarded as communicative devices that help parallel sovereignties arrive at a common understanding. Tokarski suggests that environmental philosophy can offer consolation for the discomfort that we will undoubtedly experience as a result of coexistence with wild and sometimes dangerous animals. Finally, veterinarian, legal scholar, ethicist and former hunter Charles Foster examines intuitions about the human enjoyment of killing and eating animals, from a philosophical but primarily from a personal perspective. This chapter has a different character than the other chapters, as it builds not on academic arguments, but rather on anecdotal knowledge. Hereby it aims to give the reader an experiential account of what goes on in the mind of a (former) hunter. Commentator Sjaak Swart recounts the broad range of implications of the Anthropocene for wild animals. As the cases in this section show, for some animals Anthropocene conditions are threatening, while for others they may be favourable. Can the traditional view in animal and environmental ethics that we should leave wild animals alone as much as possible be upheld when wild animals are increasingly affected by our actions? Moreover, can the categories of wild versus domesticated animals be maintained with the increasing presence of wild animals in 'human' cultural landscapes?

\subsubsection{Part 5: Animal Artefacts}

The final part focuses on 'animal artefacts': animals whose genetic make-up is changed by humans, raising the question of whether they are at least in part human artefact. Different responses are possible to the mass extinction of species we are facing in the Anthropocene. While conservationists may focus on saving species from extinction, ecomodernists want to call in the aid of technology, for example by engaging in resurrection ecology. Bringing back extinct species with the aid of technologies, such as gene drives, raises a host of moral and philosophical questions about for example dealing with risks, about human control, and about our view of nature. What would be the moral status of such 'animal artefacts'? Of course, biotechnologies are employed in other areas as well, such as reproductive technologies in livestock, and cloning in equestrian sports. How does the employment of such technologies impact human-animal relationships? Are biotechnological interventions in animal genomes instances of animal enhancement or rather animal disenhancement? 
Christopher Preston, author of The Synthetic Age, takes another look at the concept of agency, albeit on the level of the genome. Focussing on the technologies of gene sequencing, gene synthesis, and genome editing, that make possible practices such as gene drives and de-extinction, Preston critically examines the promises that such technologies hold in store for us. He argues that 'speculative ethics' around these technologies overlook their problems, caused by reductive and non-relational thinking and by a neglect of non-human agency. Jennifer Welchmann takes a closer look at the practice of de-extinction, illustrated by the case of the Heath Hen. Can it be coherently argued that we owe it to species we have driven to extinction to bring them back? Adam Shriver revisits a number of famous thought experiments around genetic modification of animals, such as the football bird, blind chickens, and painless pigs, in order to critique the way in which the concepts of enhancement and disenhancement have been demarcated. He defends a welfarist definition of disenhancement, which implies that some cases that are often regarded as disenhancement, such as painless livestock, should instead be regarded as enhancement. In her chapter, Cor van der Weele comes back to the opposition between techno optimists, such as ecomodernists, and techno sceptics, or in the words of an influential book by Charles Mann: the wizards and the prophets. Illustrating her argument with the case of cultured meat, she aims to break through this opposition and to find constructive ways of dealing with dualisms and ambivalence. Ecomodernism is also the red thread of Henk van den Belt's comment. Each of the technological practices discussed in this section forms an instance of rewriting the biosphere and engages one way or another with the techno-optimism of ecomodernists.

\section{References}

Bekoff, M., and J. Pierce. 2009. Wild justice: The moral lives of animals. Chicago: University of Chicago Press.

Bovenkerk, B. 2016. Animal captivity: Justifications for animal captivity in the context of domestication. In Animal ethics in the age of humans. Blurring boundaries in human-animal relationships, ed. B. Bovenkerk and J. Keulartz, 151-171. Dordrecht: Springer.

Bovenkerk, B., and J. Keulartz (eds.). 2016. Animal ethics in the age of humans: Blurring boundaries in human-animal relationships. Dordrecht: Springer.

Bovenkerk, B., and H. Nijland. 2017. The pedigree dog breeding debate in ethics and practice: Beyond welfare arguments. Journal of Agricultural and Environmental Ethics 30 (3): 387-412.

Brosnan, S.F., and F. de Waal. 2012. Fairness in animals: Where to from here? Social Justice Research 25 (3): 336-351.

Ceballos, G., P. Ehrlich, and R. Dirzo. 2017. Biological annihilation via the ongoing sixth mass extinction signaled by vertebrate population losses and declines. Proceedings of the National Academy of Sciences (Early Edition).

De Waal, F. 2016. Are we smart enough to know how smart animals are? New York: W.W. Norton \& Company.

Dirzo, R., H. Young, M. Galetti, G. Ceballos, N. Isaac, and B. Collen. 2014. Defaunation in the Anthropocene. Science 345 (6195), 401-406.

Donaldson, S., and W. Kymlicka. 2011. Zoopolis: A political theory of animal rights. Oxford: Oxford University Press. 
Donaldson, S. and W. Kymlicka. 2016. Comment: Between wild and domesticated: Rethinking categories and boundaries in response to animal agency. In Animal Ethics in the age of humans: Blurring boundaries in human-animal relationships, eds. B. Bovenkerk and J. Keulartz, 225-239. Dordrecht: Springer.

Gruen, L. 2011. Ethics and animals: An introduction. Cambridge: Cambridge University Press.

Irvine, L. 2004. If you tame me: Understanding our connection with animals. Philadelphia: Temple University Press.

Keulartz, J., and B. Bovenkerk. 2016. Changing relationships with non-human animals in the Anthropocene-An introduction. In Animal Ethics in the Age of Humans, ed. B. Bovenkerk and J. Keulartz, 151-171. Dordrecht: Springer.

Knol, W. 2015. Verwilderde huiskatten: effecten op de natuur in Nederland. Koninklijke Nederlandse Jagersvereniging, Amersfoort. Intern rapport nummer 15-01.

Larson, B.M.H., and S. Barr 2016. The flights of the monarch butterfly: Between. In Situ and Ex Situ Conservation. In Animal Ethics in the Age of Humans, ed. B. Bovenkerk and J. Keulartz, 355-368. Dordrecht: Springer.

Leavens, D.A. 2007. Animal cognition: Multimodal tactics of Orangutan communication. Current Biology 17 (17): 762-764.

Leuven, R. 2017. Over grenzen van soorten. Inaugurale rede. Nijmegen: Radboud Universiteit.

Linnell, J.D.C., and B. Cretois. 2018. Research for AGRI committee-The revival of wolves and other large predators and its impact on farmers and their livelihood in rural regions of Europe. European Parliament, Policy Department for Structural and Cohesion Policies, Brussels.

Lurz, R.W. (ed.). 2009. The philosophy of animal minds. Cambridge: Cambridge University Press.

Manfredo, M.J., E.G. Urquiza-Haas, A.W. Don Carlos, J.T. Bruskotter, and A.M. Dietsch. 2019. How anthropomorphism is changing the social context of modern wildlife Conservation. Biological Conservation. https://doi.org/10.1016/j.biocon.2019.108297.

Marra, P., and C. Santella. 2016. Cat wars: The devastating consequences of a cuddly killer. Princeton: Princeton University Press.

Meijer, E. 2019. When animals speak: Toward an interspecies democracy. New York: New York University Press.

Oreshkova, N., R.J. Molenaar, S. Vreman, F. Harders, B.B. Oude Munnink, R.W. Hakze-van der Honing, N. Gerhards et al. 2020. SARS-CoV-2 infection in farmed minks, the Netherlands, April and May 2020. Eurosurveillance 25 (23).

Regan, T. 1983. The case for animal rights. Berkeley: University of California Press.

Rolston III, H. 2012. A new environmental ethics: The next millennium for life on earth. New York: Routledge.

Sandom, C., S. Faurby, B. Sandel, and J.-C. Svenning. 2014. Global late quaternary megafauna extinctions linked to humans, not climate change. Proceedings of the Royal Society B 281: 20133254.

Schama, S. 1995. Landscape and memory. London: HarperCollins Publishers.

Singer, P. 1975. Animal liberation: A new ethics for our treatment of animals. New York: New York Review.

Špinka, M., and F. Wemelsfelder. 2011. Environmental challenge and animal agency. In Animal Welfare, ed. M.C. Appleby, I.A.S. Olsson, and F. Galindo, 27-44. Wallingford, UK: CAB International.

Svenning, J.-C., P. Pedersen, C.J. Donlan, R. Ejrnaes, S. Faurby, M. Galetti, et al. 2016. Science for a wilder Anthropocene: Synthesis and future direction for rewilding research. Proceedings of the National Academy of Sciences 113 (4): 898-906.

Terborgh, J., R.D. Holt, and J.A. Estes. 2010. Trophic cascades: What they are, how they work, and why they matter. In Trophic cascades: Predators, prey, and the changing dynamics of nature, ed. J. Terborgh and J.A. Estes, 1-18. Washington, DC: Island Press.

Tønnessen, M., K. Armstrong Oma, and S. Rattasepp (eds.). 2016. Thinking about animals in the age of the Anthropocene. Lanham: Lexington Books. 
Torres, A., J.A.G. Jaeger, and J.C. Alonso. 2016. Assessing largescale wildlife responses to human infrastructure development. Proceedings of the National Academy of Sciences 113 (30): 84728477.

Trouwborst, A., and H. Somsen. 2019. Domestic cats (Felis catus) and European nature conservation law-Applying the EU Birds and Habitats Directives to a significant but neglected threat to wildlife. Journal of Environmental Law, 1-25.

Wasserman, E.A., and T.R. Zentall. 2012. Comparative cognition: Experimental explorations of animal intelligence. Oxford: Oxford University Press.

Wolverton, S. 2010. The North American Pleistocene overkill hypothesis and the re-wilding debate. Diversity and Distribution 16: 874-876.

\section{Websites (All Retrieved April 8, 2020)}

https://www.nrc.nl/nieuws/2020/02/07/het-spoor-van-corona-leidt-naar-een-gestreste-vleermuisa3989708.

https://www.theguardian.com/world/2020/apr/06/bronx-zoo-tiger-tests-positive-for-coronavirus. https://www.ad.nl/binnenland/viroloog-nederland-is-vol-met-gastheren-die-een-virus-over-kun nen-dragen-br afbc59f5/.

https://aeon.co/essays/we-cant-stand-by-as-animals-suffer-and-die-in-their-billions.

https://www.vox.com/world/2020/1/8/21051756/australia-fires-climate-change-coal-politics. https://newclimate.org/wp-content/uploads/2019/12/CCPI-2020-Results_Web_Version.pdf. https://wildlife.org/survey-shows-u-s-citizens-increasingly-humanize-animals/?fbclid=IwAR30 Dxvy7q-B5Q_cxGrh9j-1eINgQWML4hLO9DjYK17e3YwYui6H40qP69E.

https://www.homesluxury.net/goose-kept-pecking-cop-until-he-decided-to-follow-her-she-leadhim-to-her-trapped-baby/?fbclid=IwAR0ofz3B7OINuAezBAhzQKIe3sRXx3Zjran513N08rP I57Pvydxx4g31f-0.

https://reviverestore.org/projects/woolly-mammoth/.

https://cdn.i-pulse.nl/autoriteitdiergeneesmiddelen/userfiles/sda\%20jaarrapporten\%20ab-gebruik/ AB-rapport\%202018/sda-rapportage-2018-def-err.pdf.

https://www.ema.europa.eu/en/veterinary-regulatory/overview/antimicrobial-resistance/europeansurveillance-veterinary-antimicrobial-consumption-esvac.

Jozef Keulartz is Emeritus Professor of Environmental Philosophy at the Radboud University Nijmegen, and senior researcher Applied Philosophy at Wageningen University and Research Centre. He has published extensively in different areas of science and technology studies, social and political philosophy, bioethics, environmental ethics and nature policy. His books include Die verkehrte Welt des Jürgen Habermas [The Topsy-Turvy World of Jürgen Habermas, Junius, 1995] and Struggle for Nature-A Critique of Radical Ecology (Routledge, 1998). He is coeditor of Pragmatist Ethics for a Technological Culture (Kluwer, 2002), Legitimacy in European Nature Conservation Policy (Springer, 2008), New Visions of Nature (Springer, 2009), Environmental Aesthetics. Crossing Divides and Breaking Ground (Fordham University Press, 2014), Old World and New World Perspectives in Environmental Philosophy (Springer, 2014), and Animal Ethics in the Age of Humans (Springer, 2016).

Bernice Bovenkerk is associate professor of philosophy at Wageningen University, the Netherlands. Her research and teaching deals with issues in animal and environmental ethics, the ethics of climate change, and political philosophy. Current topics are animal agency, the moral status of animals and other natural entities, with a particular focus on fish and insects, the ethics of 
animal domestication, animal (dis)enhancement, and deliberative democracy. In 2016 she coedited (together with Jozef Keulartz) Animal Ethics in the Age of Humans. Blurring boundaries in human-animal relationships (Springer) and in 2012 she published The Biotechnology Debate. Democracy in the face of intractable disagreement (Springer). She received her $\mathrm{PhD}$ title in political science at Melbourne University and her Master's title in environmental philosophy at the University of Amsterdam. Her homepage is https://bernicebovenkerk.com.

Open Access This chapter is licensed under the terms of the Creative Commons Attribution 4.0 International License (http://creativecommons.org/licenses/by/4.0/), which permits use, sharing, adaptation, distribution and reproduction in any medium or format, as long as you give appropriate credit to the original author(s) and the source, provide a link to the Creative Commons license and indicate if changes were made.

The images or other third party material in this chapter are included in the chapter's Creative Commons license, unless indicated otherwise in a credit line to the material. If material is not included in the chapter's Creative Commons license and your intended use is not permitted by statutory regulation or exceeds the permitted use, you will need to obtain permission directly from the copyright holder.

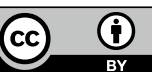

